\title{
Colistin-induced apoptosis in PC12 cells: Involvement of the mitochondrial apoptotic and death receptor pathways
}

\author{
HONG JIANG ${ }^{1,2}$, JICHANG LI ${ }^{2}$, TIEZHONG ZHOU ${ }^{1}$, CHUNHUA WANG $^{1}$, HUA ZHANG $^{3}$ and HONGJUN WANG ${ }^{1}$ \\ ${ }^{1}$ College of Animal Husbandry and Veterinary Medicine, Liaoning Medical University, Jinzhou, Liaoning 121001; \\ ${ }^{2}$ College of Veterinary Medicine, Northeast Agricultural University, Harbin, Heilongjiang 150030; \\ ${ }^{3}$ Scientific Research Department, Liaoning Medical University, Jinzhou, Liaoning 121001, P.R. China
}

Received November 27, 2013; Accepted February 28, 2014

DOI: $10.3892 /$ ijmm.2014.1684

\begin{abstract}
Colistin, a cyclic cationic polypeptide antibiotic that is used to treat infections, may cause neurotoxicity. However, whether colistin can induce apoptosis and the precise mechanism of apoptosis involved in PC12 cells remains to be determined. The aim of the present study was to determine reactive oxygen species (ROS) level and DNA damage, as well as apoptotic factors such as p53, cytochrome $c$, Bax, Bcl-2, Fas, Fas-L and caspase family via western blotting in PC12 cells treated with colistin sulfate. The results showed that colistin sulfate increased ROS levels significantly. An increase of ROS levels induces the release of cytochrome $c$ and DNA damage. DNA damage can activate p53, which leads to the upregulation of Bax and downregulation of Bcl-2. The imbalance of $\mathrm{Bax} / \mathrm{Bcl}-2$ promotes additional release of cytochrome $c$. The release of cytochrome $c$ contributes to the activation of caspase-9 and the subsequent activation of caspase-3. An increase of Fas and Fas-L induced the activation of caspase- 8 leading to the activation of caspases-3, the latter induces apoptosis. Therefore, these results demonstrate that the apoptotic pathway of colistin-induced apoptosis in PC12 cells is involved in both the mitochondrial and death receptor pathway.
\end{abstract}

\section{Introduction}

Colistin, a polymyxin $\mathrm{E}$, is a cyclic cationic polypeptide antibiotic that was initially introduced in 1952 to manage infections. Although its use was discontinued in the 1970s, colistin was used to treat infections caused by gram-negative bacteria in the early 1980s, particularly since these type of bacteria could resist almost all classes of commercially available antibiotics (1-4). Through alteration of the outer membrane permeability

Correspondence to: Professor Hongjun Wang, College of Animal Husbandry and Veterinary Medicine, Liaoning Medical University, 48 Fifth Duan, People's Street, Jinzhou, Liaoning 121001, P.R. China E-mail:1nwhj2012@163.com

Key words: colistin, PC12 cell, mitochondria, apoptotic pathway, death receptor barrier, antibiotics facilitate their own uptake and subsequently disrupt the bacterial cytoplasm membrane. However, colistin resistance rarely occurred $(5,6)$. Multidrug-resistant (MDR) bacterial infections are on the increase in hospitals, resulting in the use of colistin. However, colistin may cause renal and neurological toxicity, as reported in the 1970s. Nephrotoxicity is considered the most common adverse effect of colistin (9-50\%) (7-10). Neurological toxicity has also been reported previously (11). Although the abovementioned data are useful in gaining a better understanding of the effects of colistin on neurons and the mechanisms of colistin-induced neurotoxicity, the signaling pathways involved and the identity of its molecular targets remain to be determined.

Apoptosis is a morphological and biochemical description of a physiological cell death mechanism that is commonly associated with programmed events necessary for the differentiation and development of individuals and organs $(12,13)$. Apoptotic cell death is characterized by chromatin condensation, DNA fragmentation, cellular shrinkage, and membrane blebbing resulting in the formation of apoptotic bodies (12). Apoptosis is regulated and executed by the major protein families, Bcl-2 and caspase, which are highly conserved from worms to humans $(14,15)$. Many important observations on various signaling pathways mediating apoptotic cell death have been demonstrated. However, the mechanism of apoptosis induced by colistin remains to be elucidated.

The PC12 cell line is derived from a tumor in the rat adrenal gland and is the most widely used neuronal cell line for studying mechanisms associated with neurodegenerative disorders $(16,17)$. Over the past 30 years, PC12 cells have become a suitable model to study neuronal function and differentiation (18-20) as demonstrated in a study that used PC12 cells to study manganese-induced apoptosis in order to understand the mechanism of neurological disorders that is similar to parkinsonism (18). Consequently, PC12 cells are considered a useful model for studying the mechanism of apoptosis induced by methyl mercury, paraquat and manganese (21-23).

The present study was designed to determine whether colistin could induce apoptosis in PC12 cells as well as to examine the colistin-induced apoptotic pathway in the PC12 cells model system. First, cell viability of PC12 cells exposed to colistin was measured by MTT assay. Subsequently, analysis of 
DNA fragmentation and reactive oxygen species (ROS) level in PC12 cells treated with colistin was carried out. In addition, to determine the apoptotic pathway initiated by colistin treatment, changes of apoptotic factors such as Bax, Bcl-2, Fas, Fas-L and the caspase family in PC12 cells treated with different doses of colistin were measured by western blot analysis. The results are likely to provide information pertaining to the reduction and inhibition of the neurotoxicity of colistin for the wide application of MDR bacterial infections.

\section{Materials and methods}

Materials. Colistin sulfate (20195 U/mg), 2,7-dichlorofluorescein diacetate (DCFH-DA), anhydrous dimethyl sulfoxide (DMSO), and MTT were purchased from Sigma-Aldrich (St. Louis, MO, USA). The polyclonal goat anti-rabbit antibody against p53, cytochrome $c$, Bax, Bcl-2, Fas, Fas-L, caspase-3, caspase-8, caspase-9, IgG biotinylated antibody, bicinchoninic acid assay kit and ECL chemiluminescence detection kit were purchased from Boster Biotechnology (Wuhan, China). Dulbecco's modified Eagle's medium (DMEM) was purchased from Gibco (Scotland, UK). Fetal calf serum (FCS) was purchased from Sijiqing Biological Engineering Material (Hangzhou, China). Hoechst 33258 staining kit, lysis buffer and homogenization buffer were purchased from KeyGen Biotechnology (Nanjing, China). All other chemicals were of the highest grade and available from commercial sources. Flasks, 6-well and 96-well plates were from Costar, Corning Inc. (Corning, New York, USA).

Cell culture. The PC12 cell line was obtained from the Chinese type culture collection (CTCC, Shanghai, China). It was grown in DMEM (Life Technologies) containing $15 \% \mathrm{FBS}$ at $37^{\circ} \mathrm{C}$ in $5 \% \mathrm{CO}_{2}$ under $85-95 \%$ humidity. The cells were preincubated in $25 \mathrm{~cm}^{2}$ flasks overnight, and the medium was replaced with DMEM containing 10\% FBS every two days. Once confluent, the PC12 cells were collected with $0.025 \%$ trypsin and $0.02 \%$ EDTA (dissolved in PBS), passaged at a 1:3 dilution. Cells in the logarithmic growth phase were included for subsequent experimental procedures.

Cell viability assay. The MTT assay method was used to assess the cell viability $(24,25)$. Briefly, $\sim 1 \times 10^{4}$ cells were plated in each well of 96 -well plates. After $24 \mathrm{~h}$ incubation, the cells were treated with colistin sulfate at $0,31.25,62.5,125$, 250 and $500 \mu \mathrm{g} / \mathrm{ml}$ for $24 \mathrm{~h}$. Subsequently, the supernatant was removed, and $180 \mu \mathrm{l}$ DMEM and $20 \mu \mathrm{l}$ of $5 \mathrm{mg} / \mathrm{ml}$ of MTT (dissolved in PBS) were added to each well and incubated at $37^{\circ} \mathrm{C}$ for $4 \mathrm{~h}$. The supernatant was discarded and the purple formazan crystals were dissolved in $150 \mu \mathrm{l}$ of DMSO. The absorbance was measured at $570 \mathrm{~nm}$ with a microplate reader (Bio-Rad, Hercules, CA, USA). The viability of colistin-treated cells was expressed as a percentage compared with the noncolistin treated group (control group): Cell viability = (average absorbance value of colistin-treated group/average absorbance value of control group) x100\%. Each experiment was repeated at least three times.

Reactive oxygen species assay. To measure ROS generation, a fluorometric assay using intracellular oxidation of DCFH-DA was performed as reported previously, with slight modification (26). Following exposure to colistin sulfate at $0,62.5,125$ and $250 \mu \mathrm{g} / \mathrm{ml}$ for $24 \mathrm{~h}, \mathrm{PC} 12$ cells were incubated with $40 \mu \mathrm{M}$ DCFH-DA dissolved in DMEM in the dark for $30 \mathrm{~min}$ at $37^{\circ} \mathrm{C}$ in a $5 \% \mathrm{CO}_{2}$ atmosphere. DCFH-DA is a nonfluorescent compound, and can be enzymatically converted to the highly fluorescent compound, DCF, in the presence of ROS. After loading, the cells were washed three times with DMEM and DCF fluorescence was measured using the microplate spectrofluorometer (Molecular Devices Co., Sunnyvale, CA, USA) with excitation and emission wavelengths of 485 and $530 \mathrm{~nm}$, respectively.

Nuclear morphology detected by Hoechst 33258. Hoechst 33258 was employed to label both intact and apoptotic nuclei $(27,28)$. Cells were seeded in 96 -well plates at a density of $1 \times 10^{5}$ cells/well, followed by different concentrations of colistin sulfate $(0,62.5,125$ and $250 \mathrm{mg} / \mathrm{ml})$ treatment for $24 \mathrm{~h}$. Following treatment, the PC12 cells were washed in ice-cold PBS buffer (pH 7.4), fixed with $4 \%$ p-formaldehyde and incubated with $1 \mu \mathrm{g} / \mathrm{ml}$ Hoechst 33258 for $3 \mathrm{~min}$ at room temperature. Condensed and fragmented nuclei were evaluated by intercalation of the fluorescent probe Hoechst 33258 into nuclear DNA. Visualization was conducted at an excitation and emission wavelengths of 480 and $520 \mathrm{~nm}$, respectively, by Olympus IMT-2 fluorescence microscopy (Tokyo, Japan).

Western blotting determination. Following treatment with $0,62.5,125,250 \mu \mathrm{g} / \mathrm{ml}$ colistin sulfate for $24 \mathrm{~h}$, the cellular proteins of PC12 cells were extracted from the 6-well tissue culture plates via the addition of $100 \mu \mathrm{l}$ of lysis buffer and incubated on ice for $60 \mathrm{~min}$. Lysates were centrifuged at $10,000 \mathrm{x} \mathrm{g}$ for $10 \mathrm{~min}$ at $4^{\circ} \mathrm{C}$, and the supernatant was stored at $-80^{\circ} \mathrm{C}$ prior to electrophoresis. The protein concentration was determined by bicinchoninic acid assay. To analyze cytochrome $c$ in the cytosol, the PC12 cells were resuspended in homogenization buffer and broken by 40 strokes with a pestle in a glass homogenizer on ice. Nuclei were removed by centrifugation at $800 \mathrm{x}$ g for $10 \mathrm{~min}$. The supernatant was centrifuged at $10,000 \mathrm{x} \mathrm{g}$ for $20 \mathrm{~min}$ and collected as a cytosolic fraction. The samples ( $40 \mu \mathrm{g}$ of protein) were mixed with $2 \mathrm{X}$ sample buffer containing $100 \mathrm{mM}$ Tris- $\mathrm{HCl}$ (pH 6.8), $200 \mathrm{mM}$ dithiothreitol (DTT), 4\% sodium dodecyl sulfate (SDS), $20 \%$ glycerol and $0.2 \%$ bromophenol blue. The mixtures were boiled at $100^{\circ} \mathrm{C}$ for $10 \mathrm{~min}$ and were subjected to $12 \%$ (p53, Bax, Bcl-2, Fas, Fas-L, caspase- 8 and -9 , $\beta$-actin as parameter) and $15 \%$ (caspase- 3 and cytochrome $c, \beta$-actin as parameter) SDS-polyacrylamide minigel electrophoresis at a constant pressure of $100 \mathrm{~V}$.

Subsequently, proteins on the gel were electrotransferred onto an immobile nitrocellulose membrane (NC; Millipore, Bedford, MA, USA) with transfer buffer [25 mM Tris- $\mathrm{HCl}$ (pH 8.3), 192 mM glycine and 25\% methanol]. The membranes were blocked with blocking solution containing TBST [10 mmol/1 Tris- $\mathrm{HCl}$ (pH 7.6), 100 mmol/1 NaCl, 0.1\% Tween20], 5\% skimmed milk powder at room temperature for $2 \mathrm{~h}$, and then incubated with primary antibodies including anti-p53, anti-Bcl-2, anti-Bax, anti-cytochrome $c$, anti-caspase-9, anticaspase-3, anti-caspase-8, anti-Fas and anti-Fas-L antibodies (1:200 dilution) at $4^{\circ} \mathrm{C}$ overnight. The membranes were washed three times $(3 \times 10 \mathrm{~min})$ in TBST and incubated with 
A

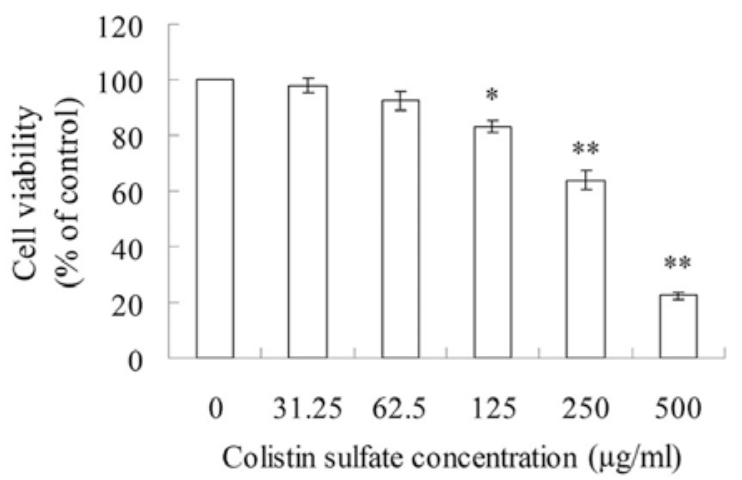

B

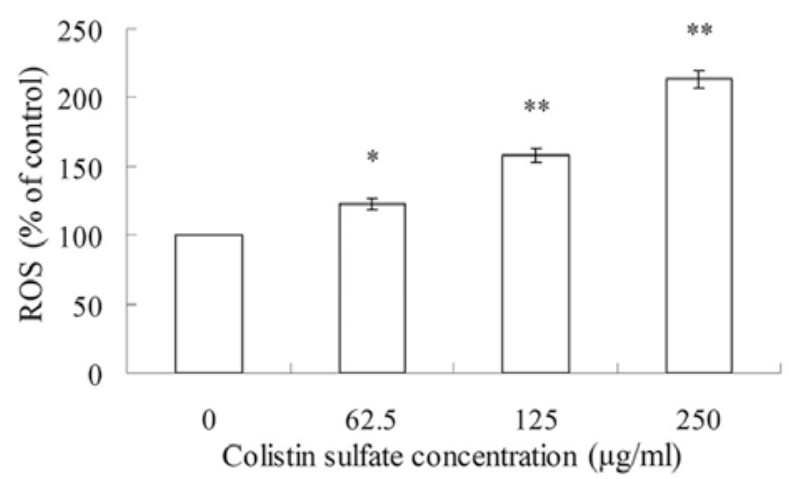

Figure 1. Cell viability and reactive oxygen species (ROS) level of colistin-treated PC12 cells. (A) Cell viability of PC12 cells treated with colistin for 24 h measured by MTT. (B) The ROS level was estimated by fluorescence assay. Cell viability and ROS level are presented as a relative percentage against the control without colistin. Concentration-dependent changes in cell viability and ROS levels in PC12 cells at 24 h after colistin exposure. The asterisk shows statistical significance in comparison with the control group $\left({ }^{*} \mathrm{P}<0.05,{ }^{* *} \mathrm{P}<0.01\right)$. Data are means \pm SEM of five independent experiments.

goat-anti-rabbit HRP polyclonal antibody (1:1,000 dilution) for $1 \mathrm{~h}$ at room temperature. The membranes were washed three times (3x10 min) with TBST and exposed to ECL chemiluminescence reagents for $1-5 \mathrm{~min}$. Detection was achieved by measuring the chemiluminescence of blotting agent (ECL) following exposure of the filters to X-Omat Kodak films. The autoradiogram was scanned and the protein bands were quantified by densitometry using Image J 1.42 software.

Statistical analysis. Data were expressed as means \pm SEM. Statistical significance was determined by one-way ANOVA, followed by the Student-Newman-Keuls test for multigroup comparisons. Differences were considered significant when $\mathrm{P}<0.05$ or $\mathrm{P}<0.01$.

\section{Results}

Cell viability evaluation. The PC12 cell viability of control cells was designated as $100 \%$. Compared with the control group, cell viability treated with colistin sulfate from 31.25 to $500 \mu \mathrm{g} / \mathrm{ml}$ was reduced from 97.7 to $22.5 \%$ in a concentration-dependent manner (Fig. 1A). When PC12 cells were exposed to $\geq 125 \mu \mathrm{g} / \mathrm{ml}$ concentration of colistin sulfate, cell viability decreased significantly $(\mathrm{P}<0.05$ or $\mathrm{P}<0.01)$.

ROS level in PC12 cells. The accumulation of oxygen-free radicals was estimated by fluorescence assay. ROS production was calculated as a percentage of the untreated control cells. As shown in Fig. 1B, the ROS level significantly $(\mathrm{P}<0.01)$ increased and had concentration-dependent changes in PC12 cells after exposure to $62.5,125$ and $250 \mu \mathrm{g} / \mathrm{ml}$ colistin sulfate for $24 \mathrm{~h}$.

Colistin-induced DNA fragmentation in PC12 cells. Colistin induced internucleosomal DNA fragmentation, which is associated with chromatin condensation. Apoptotic morphological evaluation of PC12 by Hoechst 33258 staining in inverted fluorescence microscopy was observed. As shown in Fig. 2, the increased dose of colistin sulfate, led to condensed and fragmented nuclei, which were gradually increased compared with the control group in a dose-dependent manner. These results indicated that apoptosis was induced by colistin.
Analyses of apoptosis-related factors. The effects of colistin sulfate treatment $(0-250 \mu \mathrm{g} / \mathrm{ml})$ for $24 \mathrm{~h}$ on the expression of apoptosis-related factors in PC12 cells is shown in Figs. 3-5. As shown in Fig. 3, after treatment with 62.5, 125 and $250 \mu \mathrm{g} / \mathrm{ml}$ colistin sulfate for $24 \mathrm{~h}$, the expression levels of p53 (Fig. 3A), Bax (Fig. 3B) and cytochrome $c$ (Fig. 3C) were increased and were statistically significant as compared to those of the control. By contrast, the expression of Bcl-2 decreased significantly (Fig. 3D). Therefore, the ratio of Bax/Bcl-2 increased in a concentration-dependent manner.

As shown in Fig. 4, Fas-L (Fig. 4A) and Fas (Fig. 4B) in the cell lysates released from PC12 cells treated with 62.5 , 125 and $250 \mu \mathrm{g} / \mathrm{ml}$ colistin sulfate for $24 \mathrm{~h}$ showed significant increases in comparison with that in the control cell lysates.

As shown in Fig. 5, the expression levels of caspase-3 (Fig. 5A), -9 (Fig. 5B) and -8 (Fig. 5C) in PC12 cells treated with $62.5,125$ and $250 \mu \mathrm{g} / \mathrm{ml}$ colistin sulfate for $24 \mathrm{~h}$ showed a significant increase compared with those of the control

\section{Discussion}

Nosocomial infections are an increasing public health concern worldwide that are secondary only to pan-resistant bacterial infections. However, this increase in infections is coupled with a marked decline of potentially active molecules in the pharmaceutical pipeline, particularly regarding Gram-negative infections. Colistin is a type of antibiotic that has been recently considered as the last therapeutic option for the treatment of patients with infections caused by multidrug resistant gram-negative bacteria.

Based on the results obtained from the MTT assay, concentrations of $62.5,125$, and $250 \mu \mathrm{g} / \mathrm{ml}$ colistin sulfate were used in the subsequent apoptosis-related experiments. According to the literature, it has been demonstrated that excessive generation of ROS can cause DNA damage in neurons and initiate various other effects (29). In the present study, a marked ROS burst was observed in cells treated with colistin sulfate $(62.5,125$ and $500 \mu \mathrm{g} / \mathrm{ml})$ (Fig. 1B). The marked ROS burst may explain the internucleosomal DNA fragmentation. The morphological changes of apoptotic PC12 cells induced by hydrogen peroxide were observed by Hoechst 33258 

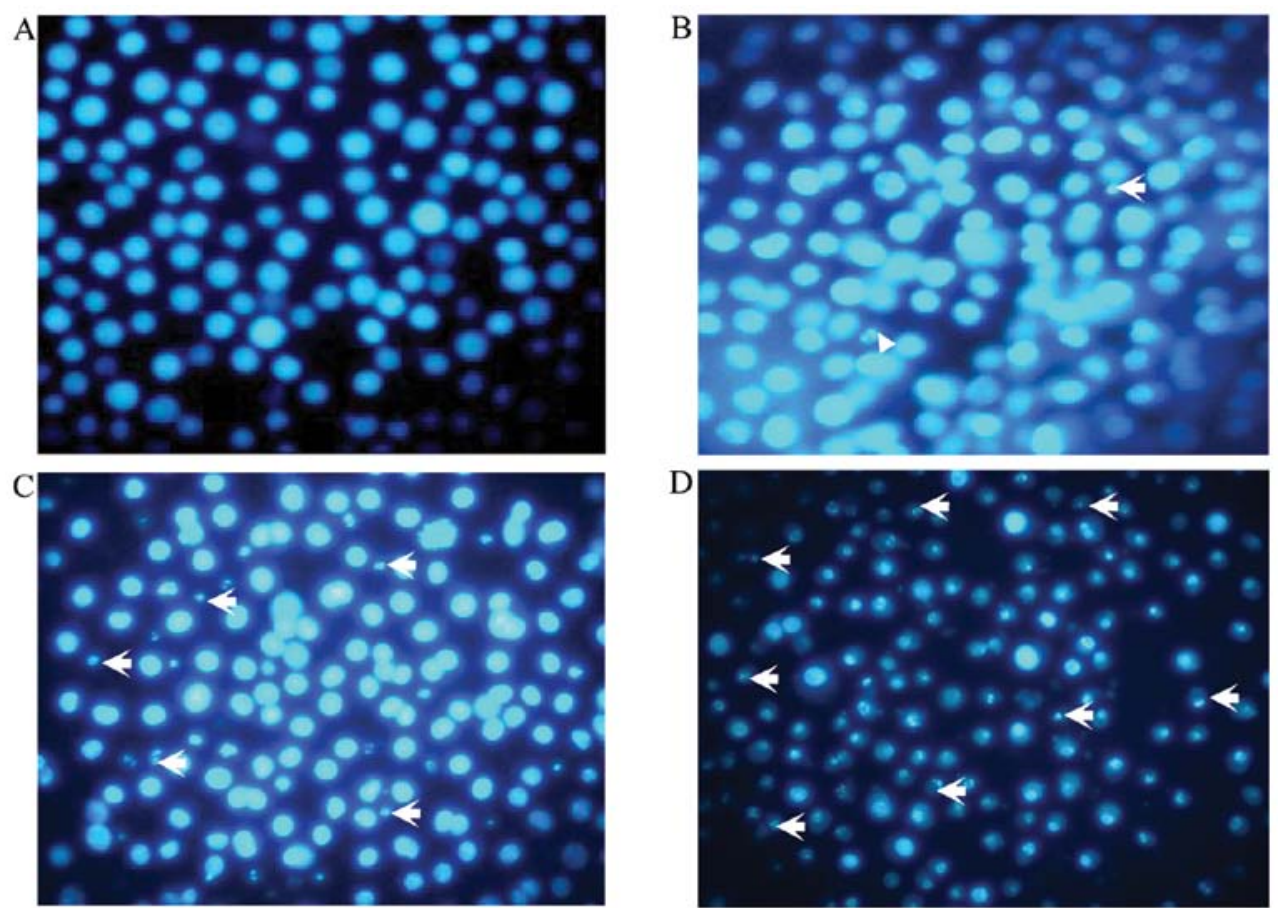

Figure 2. Apoptotic morphological evaluation of PC12 by Hoechst 33258 staining (inverted fluorescence microscopy, x200). PC12 cells treated with $0-250 \mu \mathrm{g} / \mathrm{ml}$ colistin for $24 \mathrm{~h}$. Arrows show condensed and fragmented nuclei. (A) Control group, normal cells, not condensed and fragmented in nuclei. (B-D) Treatment with 62.5, 125 and $250 \mu \mathrm{g} / \mathrm{ml}$ colistin. Condensed and fragmented in (B) few cell nuclei, (C) many cell nuclei and (D) in almost all cell nuclei.

A

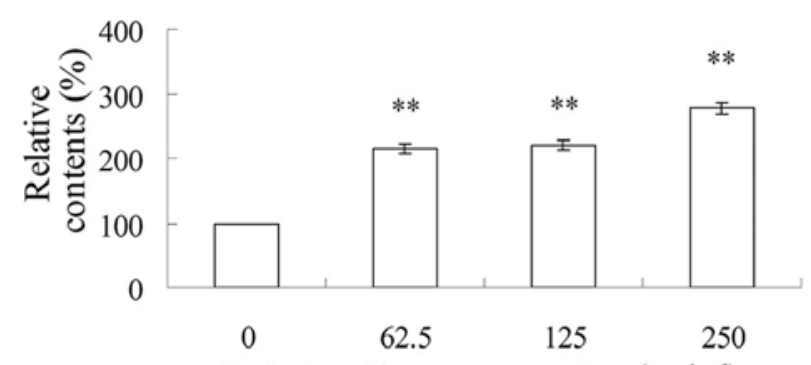

Colistin sulfate concentration $(\mu \mathrm{g} / \mathrm{ml})$

C

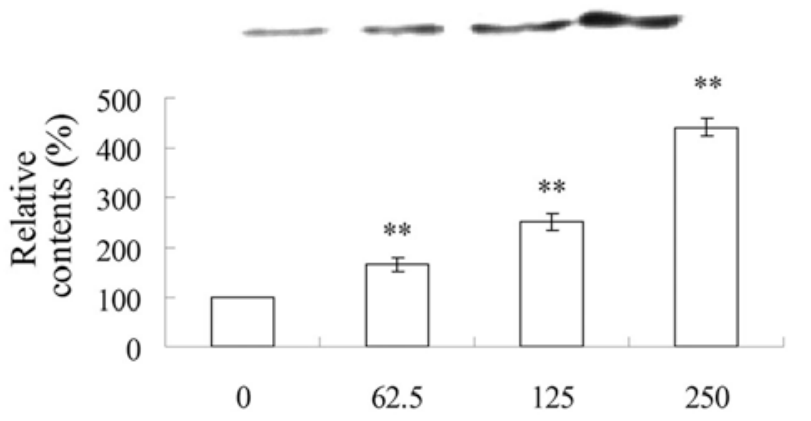

$\mathbf{E}$

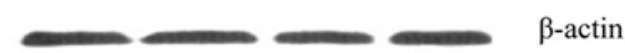

B

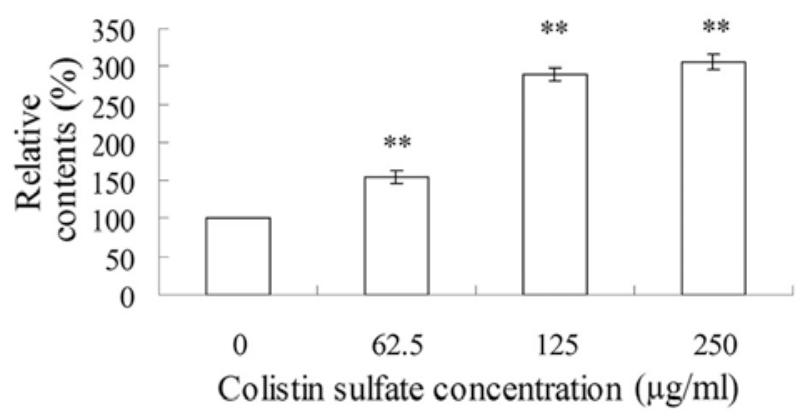

D
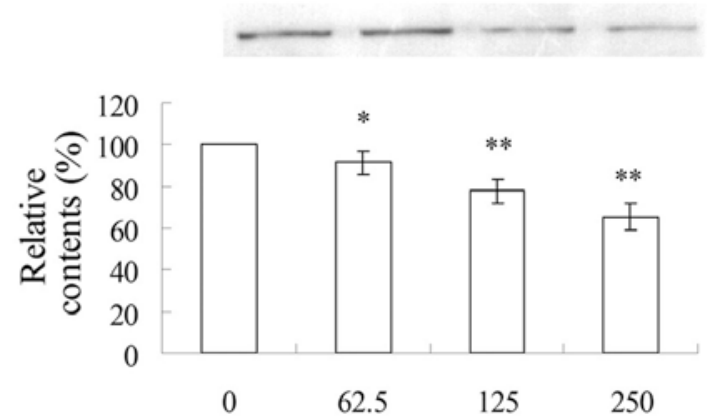

Colistin sulfate concentration $(\mu \mathrm{g} / \mathrm{ml})$

F

Figure 3. Representative western blot analyses for (A) P53, (B) Bax, (C) cytochrome $c$ and (D) Bcl-2. $\beta$-actin in (E) $15 \%$ and (F) $12 \%$ gel in the lysates from PC12 cells treated with $61.25,125$ and $250 \mu \mathrm{g} / \mathrm{ml}$ colistin sulfate for $24 \mathrm{~h}$. Relative intensities are shown by blots over the graphs. To compare the signals, those in PC12 cells without colistin were adjusted to $100 \%$. Error bars indicate SEM $(\mathrm{n}=5)$. The asterisk shows the statistical significance in comparison with $0 \mu \mathrm{g} / \mathrm{ml}$ colistin sulfate $\left({ }^{* *} \mathrm{P}<0.01\right)$. 
A

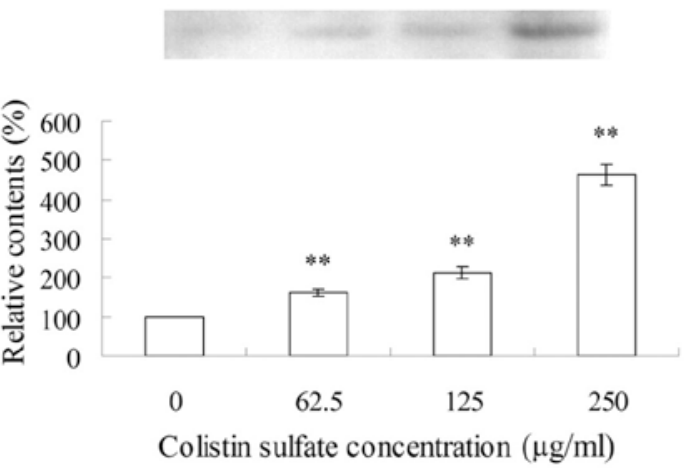

B

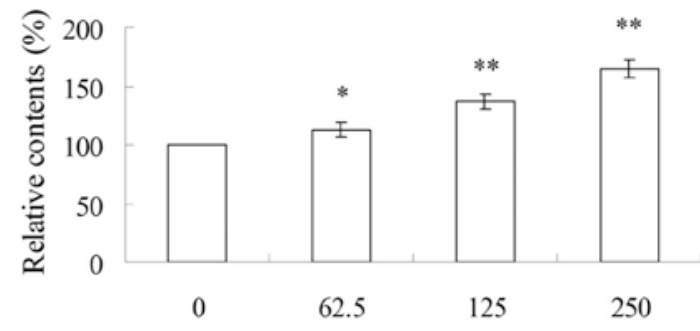

Colistin sulfate concentration $(\mu \mathrm{g} / \mathrm{ml})$

C

Figure 4. Representative western blot analyses for (A) Fas, (B) Fas-L and (C) $\beta$-actin in $12 \%$ gel in the lysates from cells treated with $62.5-250 \mu \mathrm{g} / \mathrm{ml}$ colistin for $24 \mathrm{~h}$. Relative intensity is shown by blots over the graphs. To compare the signals, those in PC12 cells without colistin were adjusted to $100 \%$. Error bars indicate SEM ( $\mathrm{n}=5),{ }^{* *} \mathrm{P}<0.01$ compared with $0 \mu \mathrm{g} / \mathrm{ml}$ colistin.

A

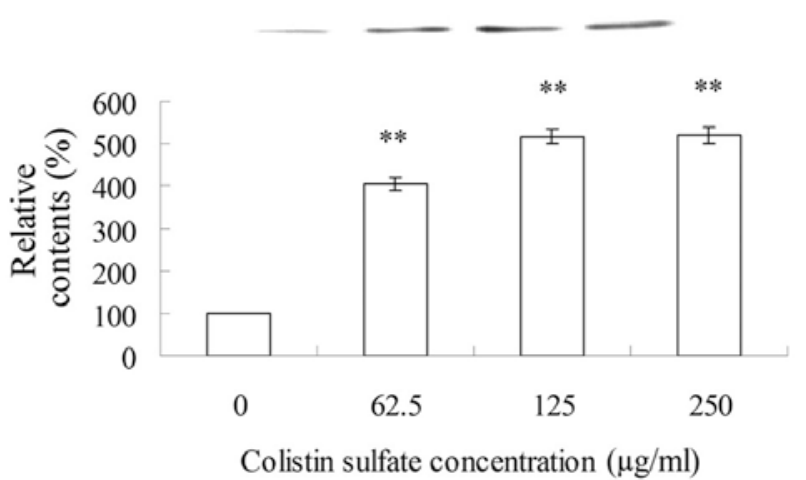

C

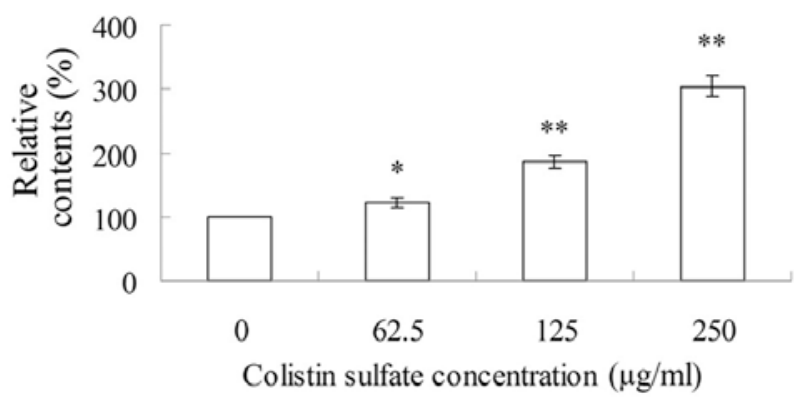

B

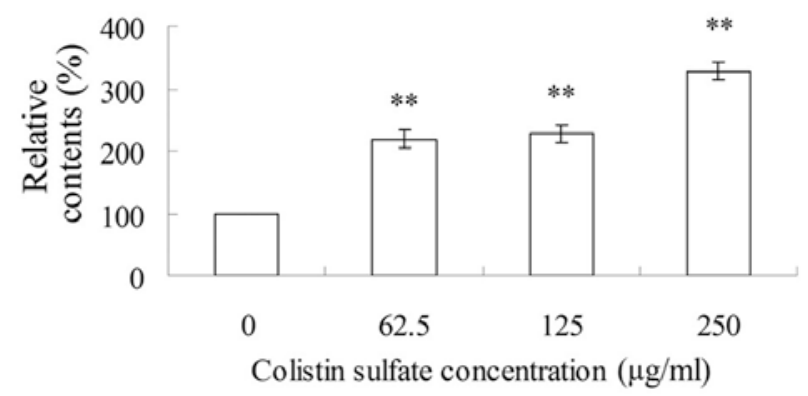

D

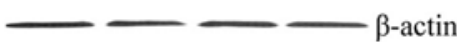

Figure 5. Representative western blot analyses for (A) caspase-3, (B) caspase-9, (C) caspase- 8 and (D) $\beta$-actin in the lysates from cells treated with $0-250 \mu$ g/ $\mathrm{ml}$ colistin for $24 \mathrm{~h}$. Relative intensity is shown by blots over the graphs. To compare the signals, those in PC12 cells without colistin were adjusted to $100 \%$. Error bars indicate SEM $(\mathrm{n}=5),{ }^{* *} \mathrm{P}<0.01$ compared with $0 \mu \mathrm{g} / \mathrm{ml}$ colistin.

staining (30). Our results indicated that colistin induced internucleosomal DNA fragmentation (Fig. 2). Notably, we found that colistin caused PC12 cell death by inducing apoptosis, as revealed by results of the western blot analysis.

Apoptosis involves two main pathways. The first pathway of apoptosis involves the participation of mitochondria, regulated by the anti- and pro-apoptotic members of the Bcl-2 family (31). The Bcl-2 family of proteins localize (or can be targeted) to mitochondria and regulate the permeability of the mitochondrial outer membrane to several apoptotic factors (32). Previous studies have shown that anti-apoptotic proteins, such as Bcl-2 and Bcl-xL, on the outer membranes of mitochondria maintain the integrity of mitochondria $(33,34)$. In response to an apoptotic stimulus, pro-apoptotic Bcl-2 members, such as Bax and Bad translocate from cytosol to mitochondria, which leads to the formation of the membrane pores at the 


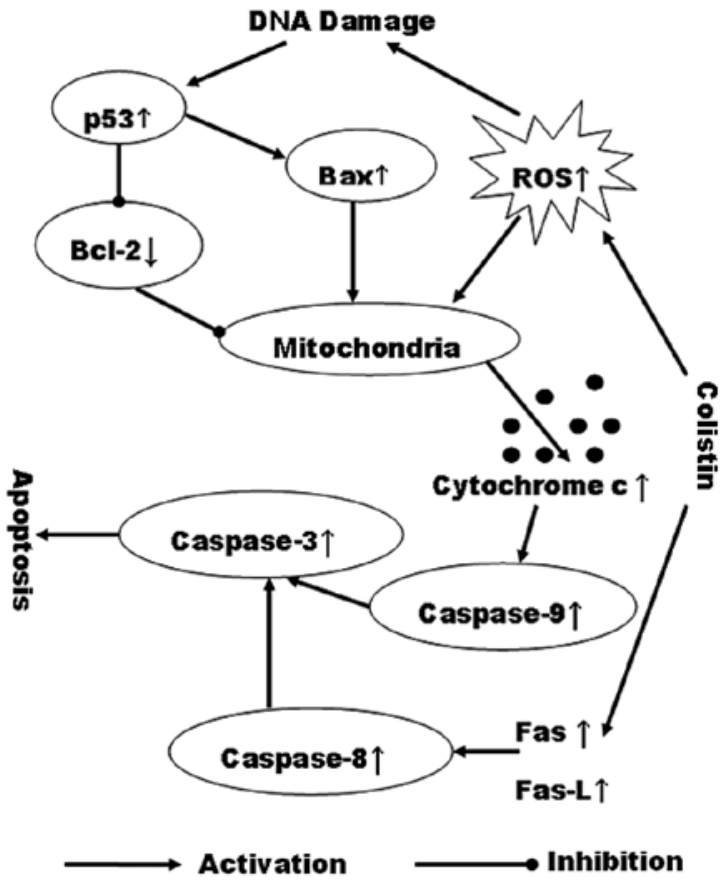

Figure 6. Possible pathway of colistin-induced apoptosis in PC12 cells.

mitochondrial membranes $(35,36)$. The translocation from the cytoplasm to mitochondria is one of the crucial steps in the Bax-mediated apoptotic process $(37,38)$. It has been suggested that Bax may have induced a decrease in the membrane potential of the mitochondria, which leads to the release of AIF and cytochrome $c$ from mitochondria $(39,40)$. While cytochrome $c$ is linked to the caspase-dependent apoptotic signaling, AIF is involved in the caspase-independent responses. Mitochondrial AIF translocates to the cytosol and then into the nucleus, binds to DNA, and induces chromatin condensation and DNA fragmentation $(41,42)$. To investigate whether the Bcl-2 family and cytochrome $c$ were involved in colistin-induced apoptosis, western blot analyses of the cell lysates from PC12 cells treated with colistin were performed using antibodies against Bax, Bcl-2 and cytochrome $c$. Results of the present study have shown that mitochondria may be pertinent in mediating apoptosis, putatively via colistin inducing the increase of ROS. ROS may trigger the subsequent release of cytochrome $c$ and DNA damage in PC12 cells, and the activation of p53 (Fig. 3A) by DNA damage, which leads to the release of cytochrome $c$ from the mitochondria (Fig. 3C). We observed appreciable changes in the expression of $\mathrm{Bcl}-2$ and $\mathrm{Bax}$ by colistin induced by PC12 cell apoptosis. Thus, the increase of Bax (Fig. 3B) and the decrease of the Bcl-2 activity in our study (Fig. 3D) may lead to an imbalance of $\mathrm{Bax} / \mathrm{Bcl}-2$ and the further release of cytochrome $c$ from the mitochondria (Fig. 3C).

The second pathway is the interaction of the cell surface receptors with their ligands, followed by the downstream activation cascade (31). After the involvement of Fas and its ligand, Fas-L, on the cell surface, Bid, a pro-apoptotic Bcl-2 family member, is cleaved by caspase- 8 . The cleavage of Bid produces a $15 \mathrm{kDa}$ truncated Bid protein (tBid), which translocates to the mitochondria membrane and triggers the release of cytochrome $c(39,43)$. We found that the expression of Fas and Fas-L increased in the colistin-treated PC12 cells (Fig. 4).
These observations suggest that the colistin-induced apoptosis in PC12 cells also occurred via the death receptor-mediated pathway.

To clarify which caspases were stimulated and increased their expression following administration of colistin, the activity of caspase-3, -8 and -9 in PC12 cells treated with $0-250 \mu \mathrm{g} / \mathrm{ml}$ colistin was measured by western blotting (Fig. 5). As shown in Fig. 5, caspase-3, -8 and -9 were activated by colistin in a dose-dependent manner. The release of cytochrome $c$ contributes to the activation of caspase- 9 and the subsequent activation of caspase-3 (Fig. 5) (44,45). The activation of caspase- 8 led to the subsequent activation of caspase-3. Subsequently, following the activation of caspase-3, colistin sulfate-induced apoptosis occurred. In this study, we found that the activity of caspase-3, -9 and -8 in PC12 cells treated with $250 \mu \mathrm{g} / \mathrm{ml}$ colistin were $\sim 5.2-, 3.3-$ and 3.0-fold compared with the control, respectively (Fig. 5A-C). Since the activity of caspase-9 was higher than that of caspase-8, it indicated that mitochondria were most pertinent in mediating apoptosis.

In conclusion, we demonstrated that colistin treatment can induce PC12 cell apoptosis via the mitochondrial and death receptor pathways (Fig. 6). A high content of colistin can increase ROS levels in PC12 cells and enhance the activation of caspase-3. Additionally, an increase of Fas and Fas-L induces activating caspase- 8 leading to the activation of caspases-3. Subsequently, after activation of caspase-3, colistin sulfate-induced apoptosis occurred. These results have demonstrated that the colistin-induced apoptosis in PC12 cells involves the complicated regulation of the mitochondrial apoptotic and death receptor pathways. Thus, our findings may provide a novel mechanism underlying the neurotoxicity of colistin.

\section{Acknowledgements}

This study was supported by the National Natural Science Foundation of China (nos. 31201951 and 31272613), and the Scientific and Technological Innovation Talent Scientific Research Foundation for the Returned Overseas Chinese Scholars by State Education Ministry and Heilongjiang Province in China (nos. 2012RFLXN005 and LC201018), and the Program for Liaoning Excellent Talents in University (no. LR2013087), and the Youth Science and Technology Foundation of Liaoning Medical University in China (no. Y2012Z023), and Liaoning province produce-learnresearch projects (LYHX2012059).

\section{References}

1. Falagas ME and Kasiakou SK: Toxicity of polymyxins: a systematic review of the evidence from old and recent studies. Crit Care 10: R27, 2006.

2. Michalopoulos A and Falagas ME: Colistin and polymyxin B in critical care. Crit Care Clin 24: 377-391, 2008.

3. Michalopoulos A, Kasiakou SK, Mastora Z, Rellos K, Kapaskelis AM and Falagas ME: Aerosolized colistin for the treatment of nosocomial pneumonia due to multidrug-resistant Gram-negative bacteria in patients without cystic fibrosis. Crit Care 9: R53-R59, 2005.

4. Zavascki AP, Goldani LZ, Li J and Nation RL: Polymyxin B for the treatment of multidrug-resistant pathogens: a critical review. J Antimicrob Chemother 60: 1206-1215, 2007.

5. Conway SP, Brownlee KG, Denton $\mathrm{M}$ and Peckham DG: Antibiotic treatment of multidrug-resistant organisms in cystic fibrosis. Am J Respir Med 2: 321-332, 2003. 
6. Littlewood JM, Koch C, Lambert PA, et al: A ten year review of colomycin. Respir Med 94: 632-640, 2000.

7. Betrosian AP, Frantzeskaki F, Xanthaki A and Douzinas EE: Efficacy and safety of high-dose ampicillin/sulbactam vs. colistin as monotherapy for the treatment of multidrug resistant Acinetobacter baumannii ventilator-associated pneumonia. J Infect 56: 432-436, 2008.

8. Furtado GH, d'Azevedo PA, Santos AF, Gales AC, Pignatari AC and Medeiros EA: Intravenous polymyxin B for the treatment of nosocomial pneumonia caused by multidrug-resistant Pseudomonas aeruginosa. Int J Antimicrob Agents 30: 315-319, 2007.

9. Holloway KP, Rouphael NG, Wells JB, King MD and Blumberg HM: Polymyxin B and doxycycline use in patients with multidrug-resistant Acinetobacter baumannii infections in the intensive care unit. Ann Pharmacother 40: 1939-1945, 2006.

10. Oliveira MS, Prado GV, Costa SF, Grinbaum RS and Levin AS: Ampicillin/sulbactam compared with polymyxins for the treatment of infections caused by carbapenem-resistant Acinetobacter spp. J Antimicrob Chemother 61: 1369-1375, 2008

11. Cheng CY, Sheng WH, Wang JT, Chen YC and Chang SC: Safety and efficacy of intravenous colistin (colistin methanesulphonate) for severe multidrug-resistant Gram-negative bacterial infections. Int J Antimicrob Agents 35: 297-300, 2010.

12. Kerr JF, Wyllie AH and Currie AR: Apoptosis: a basic biological phenomenon with wide-ranging implications in tissue kinetics. Br J Cancer 26: 239-257, 1972.

13. Maroto R and Perez-Polo JR: BCL-2-related protein expression in apoptosis: oxidative stress versus serum deprivation in PC12 cells. J Neurochem 69: 514-523, 1997.

14. Aravind L, Dixit VM and Koonin EV: The domains of death: evolution of the apoptosis machinery. Trends Biochem Sci 24: 47-53, 1999.

15. Spanos S, Rice S, Karagiannis P, et al: Caspase activity and expression of cell death genes during development of human preimplantation embryos. Reproduction 124: 353-363, 2002.

16. Meng H, Li C, Feng L, et al: Effects of Ginkgolide B on 6-OHDAinduced apoptosis and calcium over load in cultured PC12. Int J Dev Neurosci 25: 509-514, 2007.

17. Sasaki N, Toda T, Kaneko T, Baba N and Matsuo M: Flavonoids suppress the cytotoxicity of linoleic acid hydroperoxide toward PC12 cells. Biol Pharm Bull 25: 1093-1096, 2002.

18. Hirata Y: Manganese-induced apoptosis in PC12 cells. Neurotoxicol Teratol 24: 639-653, 2002.

19. Ravni A, Bourgault $S$, Lebon A, et al: The neurotrophic effects of PACAP in PC12 cells: control by multiple transduction pathways. J Neurochem 98: 321-329, 2006.

20. Vaudry D, Chen Y,Hsu CM and Eiden LE: PC12 cells as a model to study the neurotrophic activities of PACAP. Ann N Y Acad Sci 971: 491-496, 2002.

21. Hou RR, Chen JZ, Chen H, Kang XG, Li MG and Wang BR: Neuroprotective effects of (-)-epigallocatechin-3-gallate (EGCG) on paraquat-induced apoptosis in PC12 cells. Cell Biol Int 32: 22-30, 2008

22. Li Y, Shi W, Zhou Y, et al: Neuroprotective effects of chlorogenic acid against apoptosis of PC12 cells induced by methylmercury. Environ Toxicol Pharmacol 26: 13-21, 2008.

23. Shibata S, Maeda M, Furuta K, et al: Neuroprotective effects of (arylthio)cyclopentenone derivatives on manganese-induced apoptosis in PC12 cells. Brain Res 1294: 218-225, 2009.

24. Ahmadian S, Barar J, Saei AA, Fakhree MA and Omidi Y: Cellular toxicity of nanogenomedicine in MCF-7 cell line: MTT assay. J Vis Exp: 1191, 2009.

25. Peng Q, Wei $Z$ and Lau BH: Fructus corni attenuates oxidative stress in macrophages and endothelial cells. Am J Chin Med 26 291-300, 1998
26. Lee YM, Park SH, Shin DI, et al: Oxidative modification of peroxiredoxin is associated with drug-induced apoptotic signaling in experimental models of Parkinson disease. J Biol Chem 283: 9986-9998, 2008.

27. Cheng AC, Lee MF, Tsai ML, et al: Rosmanol potently induces apoptosis through both the mitochondrial apoptotic pathway and death receptor pathway in human colon adenocarcinoma COLO 205 cells. Food Chem Toxicol 49: 485-493, 2011.

28. Pan MH, Chang WL, Lin-Shiau SY, Ho CT and Lin JK: Induction of apoptosis by garcinol and curcumin through cytochrome $c$ release and activation of caspases in human leukemia HL-60 cells. J Agric Food Chem 49: 1464-1474, 2001.

29. Kawakami M, Inagawa R, Hosokawa T, Saito T and Kurasaki M: Mechanism of apoptosis induced by copper in PC12 cells. Food Chem Toxicol 46: 2157-2164, 2008.

30. Woodgate A, MacGibbon G, Walton M and Dragunow M: The toxicity of 6-hydroxydopamine on PC12 and P19 cells. Brain Res Mol Brain Res 69: 84-92, 1999.

31. Martin SJ and Green DR: Protease activation during apoptosis: death by a thousand cuts? Cell 82: 349-352, 1995.

32. Breckenridge DG and Xue D: Regulation of mitochondrial membrane permeabilization by BCL-2 family proteins and caspases. Curr Opin Cell Biol 16: 647-652, 2004.

33. Kluck RM, Bossy-Wetzel E, Green DR and Newmeyer DD: The release of cytochrome $\mathrm{c}$ from mitochondria: a primary site for Bcl-2 regulation of apoptosis. Science 275: 1132-1136, 1997.

34. Yang X, Wang Y, Luo J, Liu S and Yang Z: Protective effects of YC-1 against glutamate induced PC12 cell apoptosis. Cell Mol Neurobiol 31: 303-311, 2011.

35. Basanez G, Sharpe JC, Galanis J, Brandt TB, Hardwick JM and Zimmerberg J: Bax-type apoptotic proteins porate pure lipid bilayers through a mechanism sensitive to intrinsic monolayer curvature. J Biol Chem 277: 49360-49365, 2002.

36. Luo X, Budihardjo I, Zou H, Slaughter C and Wang X: Bid, a $\mathrm{Bcl} 2$ interacting protein, mediates cytochrome $\mathrm{c}$ release from mitochondria in response to activation of cell surface death receptors. Cell 94: 481-490, 1998.

37. Goping IS, Gross A, Lavoie JN, et al: Regulated targeting of BAX to mitochondria. J Cell Biol 143: 207-215, 1998.

38. Gross A, Jockel J, Wei MC and Korsmeyer SJ: Enforced dimerization of BAX results in its translocation, mitochondrial dysfunction and apoptosis. EMBO J 17: 3878-3885, 1998.

39. Eskes R, Desagher S, Antonsson B and Martinou JC: Bid induces the oligomerization and insertion of Bax into the outer mitochondrial membrane. Mol Cell Biol 20: 929-935, 2000.

40. Narita M, Shimizu S, Ito T, et al: Bax interacts with the permeability transition pore to induce permeability transition and cytochrome c release in isolated mitochondria. Proc Natl Acad Sci USA 95: 14681-14686, 1998.

41. Candé C, Cecconi F, Dessen P and Kroemer G: Apoptosisinducing factor (AIF): key to the conserved caspase-independent pathways of cell death? J Cell Sci 115: 4727-4734, 2002.

42. Candé C, Cohen I, Daugas E, et al: Apoptosis-inducing factor (AIF): a novel caspase-independent death effector released from mitochondria. Biochimie 84: 215-222, 2002.

43. Wei MC,Lindsten T, Mootha VK, et al: tBID, a membrane-targeted death ligand, oligomerizes BAK to release cytochrome c. Genes Dev 14: 2060-2071, 2000.

44. Csokay B, Prajda N, Weber G and Olah E: Molecular mechanisms in the antiproliferative action of quercetin. Life Sci 60 2157-2163, 1997.

45. Zimmermann KC and Green DR: How cells die: apoptosis pathways. J Allergy Clin Immunol 108: S99-S103, 2001. 